\title{
Paper
}

\section{High Density Sintered Stainless Steel}

\author{
Koki Kanno ${ }^{\hbar 1}$, Yoshinobu Takeda ${ }^{\text {tr1 }}$ and Ricardo Canto Leyton ${ }^{\not 2}$ \\ ${ }^{4}$ Höganäs Japan, 2-19 Akasaka, 4-chome Minato-ku, Tokyo 107-0052, Japan \\ ${ }^{2}$ Höganäs AB, S-263 83 Höganäs, Sweden
}

Received August, 2003

\begin{abstract}
SYNOPSIS
At present, most stainless steel materials are sintered at high temperatures to achieve the desired mechanical, corrosion and high-temperature properties through densification. Although this method of processing achieves the desired properties, the resulting dimensional change can be difficult to control. A potential alternative to reduce the amount of densification required would be stainless steel powders with higher compressibility, which can reach higher green densities at reasonable compaction pressures. The purpose of this paper will be to compare different techniques to attain the desired sintered properties. The mechanical properties and green and sintered densities reached with these techniques will also be discussed.
\end{abstract}

KEY WORDS

Stainless steel powder, Warm compaction, Corrosion test, Green strength, Dimensional change

\section{Introduction}

Stainless powder is mostly used to make car components. Some components are required to withstand severe conditions. In order to meet a requirement such as this, a higher density than $7.2 \mathrm{~g} / \mathrm{cm}^{3}$ provides satisfactory durability $^{1-3)}$ against corrosions and oxidation. Elevated sintering temperatures (above $1250^{\circ} \mathrm{C}$ ) are necessary to achieve these kinds of densities.

One way of reaching higher sintered densities, and thus better mechanical properties, is to increase the compressibility of the powder. An effective way of doing so is by warm compaction, a technique ${ }^{4)}$ already shown to increase compressibility of stainless steels with about $0.2 \mathrm{~g} / \mathrm{cm}^{3}$. Another advantage with the warm compaction technique is that, in general, it creates an even density within the component $t^{5}$. This indicates a possibility for manufacturing high-density P/M stainless steel components, e.g. exhaust flanges or HEGOS bosses, with close tolerances.

409L is commonly used in the production of exhaust flanges that require a sintered density of $>7.2 \mathrm{~g} / \mathrm{cm}^{3} .316 \mathrm{~L}$ is commonly used in the stainless steel $\mathrm{P} / \mathrm{M}$ industry, but its field of application could increase further if a sintered density $>7.2 \mathrm{~g} / \mathrm{cm}^{3}$ can be reached in a more effective way than today.

The study of dimensional change of stainless powder may help PM manufactures when considering the tendency of both material and process.

\section{Experimenal Procedure}

\subsection{Material}

The powders used for this study are as-atomised 409L and $316 \mathrm{~L}$ with a particle size $<150 \mu \mathrm{m}$. The theoretical densities of $409 \mathrm{~L}$ and $316 \mathrm{~L}$ are around $7.7 \mathrm{~g} / \mathrm{cm}^{3}$ and $8.0 \mathrm{~g} / \mathrm{cm}^{3}$ respectively. The composition and particle size of these materials are shown in Table 1 and Table 2.

Five different mixes were made, the mixes for conventional compaction contain $1.0 \%$ amide wax and $0.2 \%$ Lithium stearate as lubricants. The amide wax is an ethylene-bisstearamide (EBS), also known as Acrawax ${ }^{\circledR}$ C. The other mixes contain a lubricant designed for warm compaction

Table 1 Chemical composition of the base powder.

\begin{tabular}{|c|c|c|c|c|c|c|}
\hline Material & $\begin{array}{c}\mathbf{C r} \\
(\boldsymbol{\%})\end{array}$ & $\begin{array}{c}\mathbf{N i} \\
(\boldsymbol{\%})\end{array}$ & $\begin{array}{c}\mathbf{S i} \\
(\boldsymbol{\%})\end{array}$ & $\begin{array}{c}\mathbf{M n} \\
(\boldsymbol{\%})\end{array}$ & $\begin{array}{c}\mathbf{N b} \\
(\boldsymbol{\%})\end{array}$ & $\begin{array}{c}\mathbf{C} \\
(\boldsymbol{\%})\end{array}$ \\
\hline $409 \mathrm{~L}$ & 12.2 & 0.1 & 0.8 & 0.1 & 0.6 & 0.01 \\
\hline $316 \mathrm{~L}$ & 16.9 & 12.8 & 0.8 & 0.1 & 0 & 0.02 \\
\hline
\end{tabular}

Table 2 Particle size of distribution of the base powder.

\begin{tabular}{|c|c|c|c|}
\hline Material & $\begin{array}{c}-45 \\
\mu \mathrm{m}\end{array}$ & $\begin{array}{c}\mathbf{4 5 - 1 0 6} \\
\mu \mathrm{m}\end{array}$ & $+\mathbf{1 0 6} \mu \mathrm{m}$ \\
\hline $409 \mathrm{~L}$ & $32 \%$ & $54 \%$ & $14 \%$ \\
\hline $316 \mathrm{~L}$ & $49 \%$ & $47 \%$ & $4 \%$ \\
\hline
\end{tabular}


in the amount of $1.2 \mathrm{wt} \%$. The mixes were referred to as $409 c, 316 c$ (c for conventional compaction) and $409 w 316 w$ (w for warm compaction), with an additional mix $316 p$, as seen in Table 3. $0.5 \%$ phosphorous was added to this mix as $\mathrm{Fe}_{3} \mathrm{P}(-30 \mu \mathrm{m})$ to activate the sintering, and make the target density reachable.

\subsection{Compaction and sintering}

Tensile strength (TS) test bars, and transverse rupture strength (TRS) test bars according to ISO 2740 and ISO 3995 were compacted at $700 \mathrm{Mpa}$ by both conventional compaction and warm compaction. In the case of warm compaction, a temperature of $100^{\circ} \mathrm{C}$ was used for both powder and tool.

Those bars were sintered at several temperatures $(1280$, 1340 and $1250^{\circ} \mathrm{C}$ ) for $45 \mathrm{~min}$. in $100 \% \mathrm{H}_{2}$ atmosphere. A sintering temperature of $1280^{\circ} \mathrm{C}$ was used for $409 \mathrm{~L}$. To obtain the required density, conventional compaction followed by densification with high temperature sintering is common practice. As compared to ferritic grade 409L austenitic grade $316 \mathrm{~L}$ does not shrink as much during sintering, and to reach a density of $>7.2 \mathrm{~g} / \mathrm{cm}^{3}$ with conventional compaction very high sintering temperatures are needed $\left(>1340^{\circ} \mathrm{C}\right)$.

In order to reach the target density, it was necessary to sinter the conventionally compacted $316 c$ at a temperature of $1340^{\circ} \mathrm{C}$, while a temperature of $1250^{\circ} \mathrm{C}$ was sufficient for both $316 \mathrm{p}$ and $316 \mathrm{w}$ (see Table 3).

\subsection{Evaluations}

Chemical composition and particle size of distribution were analysed according to ISO 7625 and 4497 respectively.

Green Density and Green Strength were measured according to ISO 3927 and 3995. Sintered Density was measured according to ISO 2738 and Dimensional Change was evaluated according to ISO 4492. Then Mechanical properties were measured according to ISO 4498 and 2740.

Table 3 Mixes and procedures used.

\begin{tabular}{|c|l|c|c|}
\hline Mix & Lubricant & Sintering & $\begin{array}{c}\text { Target } \\
\text { Density } \\
\left(\mathrm{g} / \mathrm{cm}^{3}\right)\end{array}$ \\
\hline $409 \mathrm{c}$ & $\begin{array}{l}1.0 \% \text { Amide Wax } \\
+0.2 \% \text { Lithium- } \\
\text { stearate }\end{array}$ & $\begin{array}{c}1280{ }^{\circ} \mathrm{C}, 45 \\
\min , \mathrm{H}_{2}\end{array}$ & 7.3 \\
\hline $409 \mathrm{w}$ & $\begin{array}{l}1.2 \% \text { lubricant for } \\
\text { warm compaction }\end{array}$ & $\begin{array}{c}1280{ }^{\circ} \mathrm{C}, 45 \\
\min , \mathrm{H}_{2}\end{array}$ & 7.3 \\
\hline $316 \mathrm{c}$ & $\begin{array}{l}1.0 \% \text { Amide Wax } \\
+0.2 \% \text { Lithium- } \\
\text { stearate }\end{array}$ & $\begin{array}{c}1340{ }^{\circ} \mathrm{C}_{4}, 45 \\
\min , \mathrm{H}_{2}\end{array}$ & 7.2 \\
\hline $316 \mathrm{w}$ & $\begin{array}{l}1.2 \% \text { lubricant for } \\
\text { warm compaction }\end{array}$ & $\begin{array}{c}1250^{\circ} \mathrm{C}, 45 \\
\min , \mathrm{H}_{2}\end{array}$ & 7.2 \\
\hline $316 \mathrm{p}$ & $\begin{array}{l}1.0 \% \text { Amide Wax } \\
+0.5 \% \text { P }\end{array}$ & $\begin{array}{c}1250^{\circ} \mathrm{C}, 45 \\
\min , \mathrm{H}_{2}\end{array}$ & 7.2 \\
\hline
\end{tabular}

\section{Results and Discussions}

\subsection{Green properties}

After compaction green density and green strength were measured. The results can be seen in Table 4, and are illustrated in Fig. 1 and Fig. 2.

The use of warm compaction proves beneficial by increasing the as-compressed density with $0.2 \mathrm{~g} / \mathrm{cm}^{3}$ for $409 \mathrm{~L}$ and $0.3 \mathrm{~g} / \mathrm{cm}^{3}$ for $316 \mathrm{~L}$ compared to conventional compaction (Fig. 1).

The phosphorous addition reduces the green density somewhat (Fig. 1). The green density of $316 \mathrm{~L}$ reached a value of over $6.9 \mathrm{~g} / \mathrm{cm}^{3}$ when warm compacted.

Another advantage when using the warm compaction technique is the increased green strength, (Fig. 2) partly due to the increased green density and partly due to the special type of lubricant used in this mix. ${ }^{5)}$

Table 4 Green properties of the mixes.

\begin{tabular}{|c|c|c|c|}
\hline Mix & Pressure & $\begin{array}{c}\text { Green } \\
\text { Density } \\
\left(\mathbf{g} / \mathbf{c m}^{\mathbf{3}}\right)\end{array}$ & $\begin{array}{c}\text { Green } \\
\text { Strength } \\
\text { (Mpa) }\end{array}$ \\
\hline 409c & 700 & 6.63 & 9.3 \\
\hline $409 \mathrm{w}$ & 700 & 6.83 & 16.6 \\
\hline $316 \mathrm{c}$ & 700 & 6.62 & 9.9 \\
\hline $316 \mathrm{w}$ & 700 & 6.94 & 18.2 \\
\hline $316 \mathrm{p}$ & 700 & 6.57 & 11.7 \\
\hline
\end{tabular}

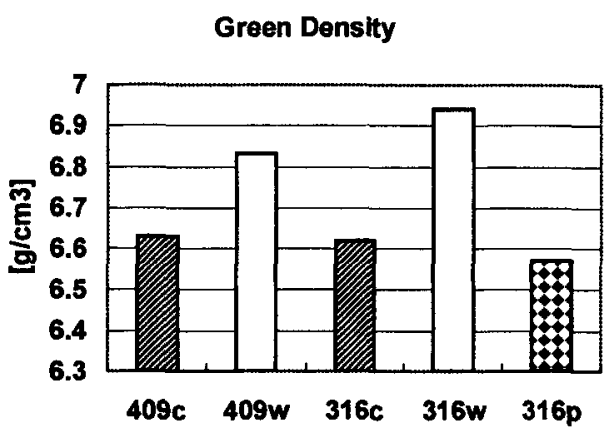

Fig.1 Green Density of 409L and 316L.

Green Strength

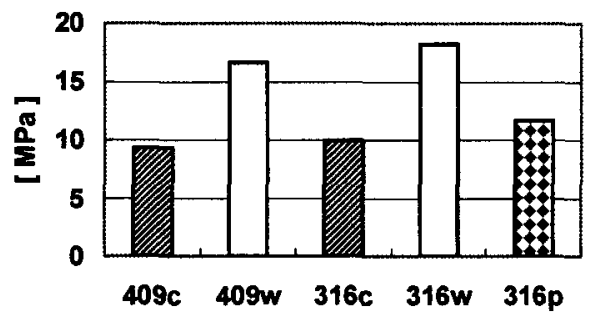

Fig.2 Green Strength of 409L and 316L. 
In the case of 409L, the green strength is increased from a value of $9.3 \mathrm{MPa}$ to a value over $16.6 \mathrm{MPa}$. The strength at green state is important because a higher value makes the components less fragile, and thus cracks are not formed as easily. This simplifies the handling of produced components.

The values for $316 w$ demonstrate an almost twice as high green strength compared to conventional compaction. The value of $\sim 18 \mathrm{MPa}$ indicates the possibility of performing green machining, a technique that could potentially increase the application field of this material. $316 p$ has a higher green strength than the reference mix (316c). This tendency has been witnessed before, e.g. for phosphorous additions to $\operatorname{ASC} 100.29^{\circ}$

\subsection{Sintered properties}

The results for density and dimensional change are given in Table 5. The values for density were measured on two TS-bars for each material. Dimensional change was measured as an average of $15 \mathrm{TS}$ bars for each.

In the case of $409 \mathrm{~L}$, the difference in sintered density between the two investigated materials compacted at room temperature and warm is about $0.1 \mathrm{~g} / \mathrm{cm}^{3}$ as compared to $0.2 \mathrm{~g} / \mathrm{cm}^{3}$ before sintering. This indicates that after a certain density level, when the sintered part approaches the theoretical density, the sintering activity starts to decrease. Since $409 w$ has a higher green density, this effect takes place earlier in the sintering process, resulting in lower dimensional change. Due to this fact, the difference in sintered densities between $409 c$ and $409 w$ is lower than the difference in green density. The results for sintered density and dimensional change are shown in Fig. 3 and 4.

The diagram in Fig. 5 is the result of a separate study using 409L. The measurements were made on TS-bars sintered in a lifting hearth furnace, with the parameters explained under the Fig. 5. It represents the dimensional change needed in order to reach a certain sintered density, having the sintering temperature as variable.

In the case of $316 \mathrm{~L}$, the target density of $7.2 \mathrm{~g} / \mathrm{cm}^{3}$ was surpassed with mixes $316 p$ and $316 w$. The conventional mix $(316 c)$ reached an acceptable value of $7.18 \mathrm{~g} / \mathrm{cm}^{3}$. From Table 5 and Fig. 3, it can be seen that $316 \mathrm{w}$ reached the target density with a margin of $0.04 \mathrm{~g} / \mathrm{cm}^{3}$, with $90^{\circ} \mathrm{C}$ lower sintering temperature than $316 \mathrm{c}$ and the lowest dimensional change (green to sintered). The phosphorous containing mix, 316p that was compacted and sintered in the same way as $316 \mathrm{w}$ demonstrates the highest dimensional change value. Higher dimensional change normally also generates higher dimensional scatter between the parts which normally reduces tolerances.

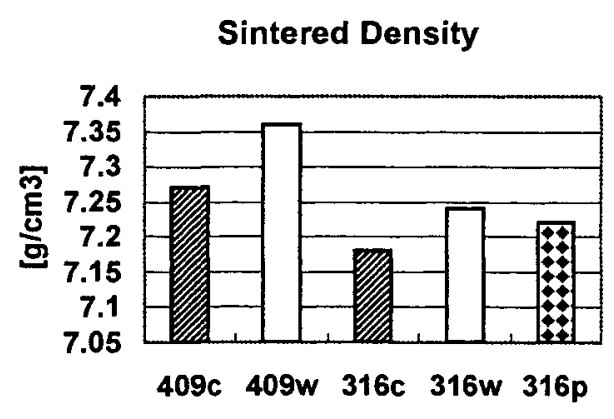

Fig.3 Sintered Density of 409L and 316L.

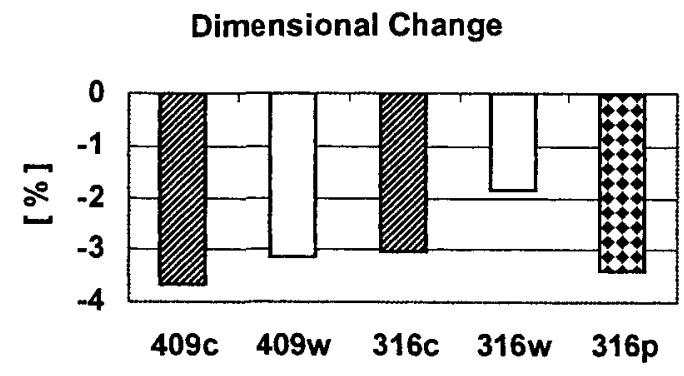

Fig.4 Dimensional Change of 409L and 316L.

Table 5 Densities and Dimensional change of mixes.

\begin{tabular}{|c|l|c|c|c|c|c|}
\hline Mix & Compaction & $\begin{array}{c}\text { Pressure } \\
(\mathbf{M p a})\end{array}$ & Sintering & $\begin{array}{c}\text { Green } \\
\text { Density } \\
\left(\mathbf{g} / \mathbf{c m}^{3}\right)\end{array}$ & $\begin{array}{c}\text { Sintered } \\
\text { Density } \\
\left(\mathrm{g} / \mathbf{c m}^{\mathbf{3}}\right)\end{array}$ & $\begin{array}{c}\text { Dimensional } \\
\text { change } \\
(\%)\end{array}$ \\
\hline $409 \mathrm{c}$ & Conventional & 700 & $\begin{array}{c}1280{ }^{\circ} \mathrm{C}, 45 \\
\min , \mathrm{H}_{2}\end{array}$ & 6.65 & 7.27 & -3.66 \\
\hline $409 \mathrm{w}$ & Warm & 700 & $\begin{array}{c}1280{ }^{\circ} \mathrm{C}, 45 \\
\min , \mathrm{H}_{2}\end{array}$ & 6.83 & 7.36 & -3.13 \\
\hline $316 \mathrm{c}$ & Conventional & 700 & $\begin{array}{c}1340{ }^{\circ} \mathrm{C}, 45 \\
\min , 100 \% \mathrm{H}_{2}\end{array}$ & 6.62 & 7.18 & -3.06 \\
\hline $316 \mathrm{w}$ & Warm & 700 & $\begin{array}{c}1250{ }^{\circ} \mathrm{C}, 45 \\
\min , 100 \% \mathrm{H}_{2}\end{array}$ & 6.94 & 7.24 & -1.84 \\
\hline $316 \mathrm{p}$ & Conventional & 700 & $\begin{array}{c}1250{ }^{\circ} \mathrm{C}, 45 \\
\min , 100 \% \mathrm{H}_{2}\end{array}$ & 6.57 & 7.22 & -3.39 \\
\hline
\end{tabular}




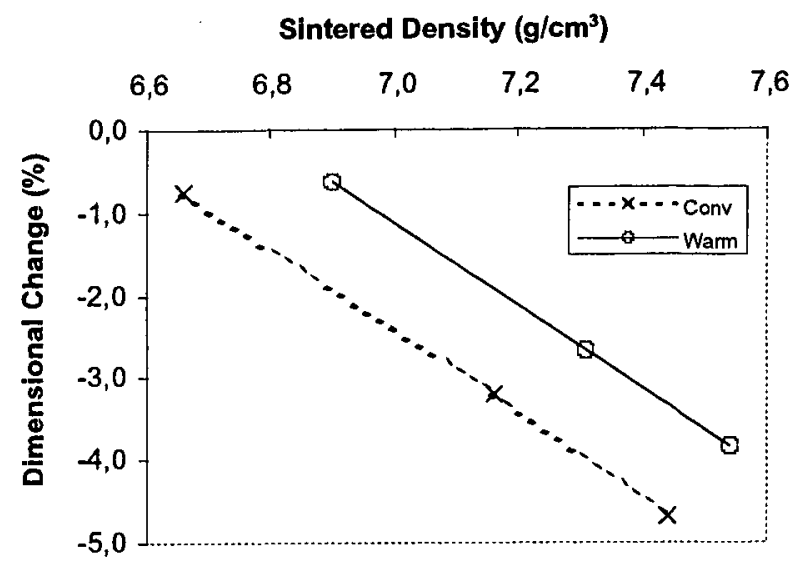

Figure 5. Dimensional change vs

Sintered density for $409 \mathrm{~L}$.

Pressure $=700 \mathrm{MPa}$

Sintering time $=45 \mathrm{~min}$.

Sintering temperatures $=1160,1250$ and

$1340{ }^{\circ} \mathrm{C}$

Sintering atmosphere $=100 \% \mathrm{H}_{2}$

Fig.5 Dimensional Change vs Sintered Density for 409L.

From this diagram it can be seen that warm compaction in general demands less dimensional change and reaches higher densities than conventional compaction. The results obtained confirm this trend. In order to get a sufficient tolerance, increase of green density is necessary. Therefore $316 \mathrm{~L}$ is more suitable for this than $409 \mathrm{~L}$ at this process condition.

\subsection{Mechanical properties of 410L and 316}

The results for mechanical properties are given in Table 6 . The values presented are an average of 15 measurements.

The mechanical properties of $316 \mathrm{~L}$ were better than that of 409L. One of the reasons can be explained by increase of sintering activity due to finer powder for $316 \mathrm{~L}$ than $410 \mathrm{~L}$ and no reaction with Nitrogen gas. The tensile and yield strength of warm compacted were slightly superior to that of conventional one but the densification (shrinkage) level
Tensile Strength of 409L and $316 \mathrm{~L}$

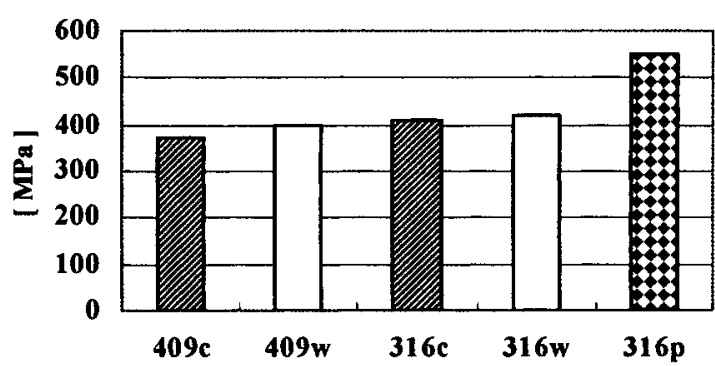

Fig.6 Tensile Strength of 409L and 316L.

of the parts were half. $316 p$ had superior tensile and yield strength to the other two mixes. This result is congruent to what is found for low-alloy $\mathrm{P} / \mathrm{M}$ powders with phosphorous additions at the same sintered density ${ }^{6}$, e.g. ASC100.29. This can be explained by the effect of phosphorous on shrinkage, pore shape and solution strength. The densification level for $316 p$ was the highest. Regarding Young's Modulus, that of 316P was a bit far from Mac Adam's law (1951).

Though there are lots of factors on mechanical properties, more considerations will be necessary in future to improve them more.

\subsection{Dimensional stability of SUS 409}

A set of 500 rings made of SUS409L were compacted at the same conditions using a 45 - ton mechanical press, equipped with a slot heater system and electrical heating of the tools, in order to evaluate the dimensional stability when using warm compaction. The dimensions of the rings were the following: inner diameter $25.4 \mathrm{~mm}$, outer diameter $35.1 \mathrm{~mm}$ and height $10 \mathrm{~mm}$. 5 rings per 100 compacted were measured and then sintered (a total of 50 rings per mix) in a ceramic belt type furnace with ceramic trays. The sintering condition was $1282^{\circ} \mathrm{C}$ for $20 \mathrm{~min}$ in an atmosphere of $50 \% \mathrm{H}_{2} / 50 \% \mathrm{~N}_{2}$.

The outer diameter was measured as two perpendicular lines. By calculating the difference as an absolute value, a

Table 6 Mechanical properties of mixes.

\begin{tabular}{|c|c|c|c|c|c|c|}
\hline Mix & $\begin{array}{c}\text { Sintered } \\
\text { Density } \\
\left(\mathbf{g} / \mathbf{c m}^{\mathbf{3}}\right)\end{array}$ & $\begin{array}{c}\text { Hardness } \\
(\mathbf{H V 1 0})\end{array}$ & $\begin{array}{c}\text { Ultimate Tensile } \\
\text { Strength } \\
(\mathbf{M p a})\end{array}$ & $\begin{array}{c}\text { Yield } \\
\text { Strength } \\
(\mathbf{M P a})\end{array}$ & $\begin{array}{c}\text { Young's } \\
\text { Modulus } \\
(\mathbf{G p a})\end{array}$ & $\begin{array}{c}\text { Elongation } \\
(\%)\end{array}$ \\
\hline $409 \mathrm{c}$ & 7.27 & 101 & 370 & - & 151 & 16.7 \\
\hline $409 \mathrm{w}$ & 7.36 & 105 & 397 & - & 157 & 17.4 \\
\hline $316 \mathrm{c}$ & 7.18 & 91 & 410 & 171 & 142 & 33.7 \\
\hline $316 \mathrm{w}$ & 7.24 & 94 & 419 & 204 & 148 & 28.0 \\
\hline $316 \mathrm{p}$ & 7.22 & 142 & 549 & 297 & 162 & 28.6 \\
\hline
\end{tabular}




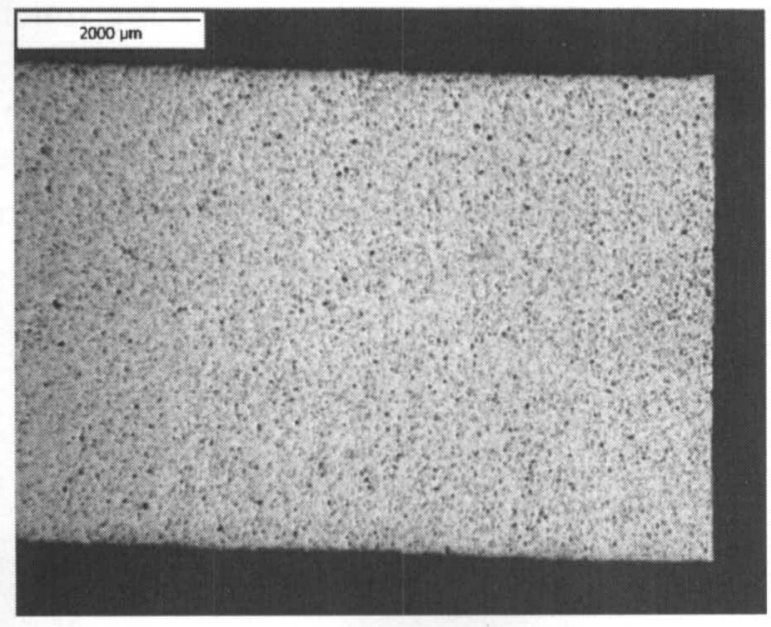

Fig.7-1 Cross section of 316w TS-bar at low magnification.

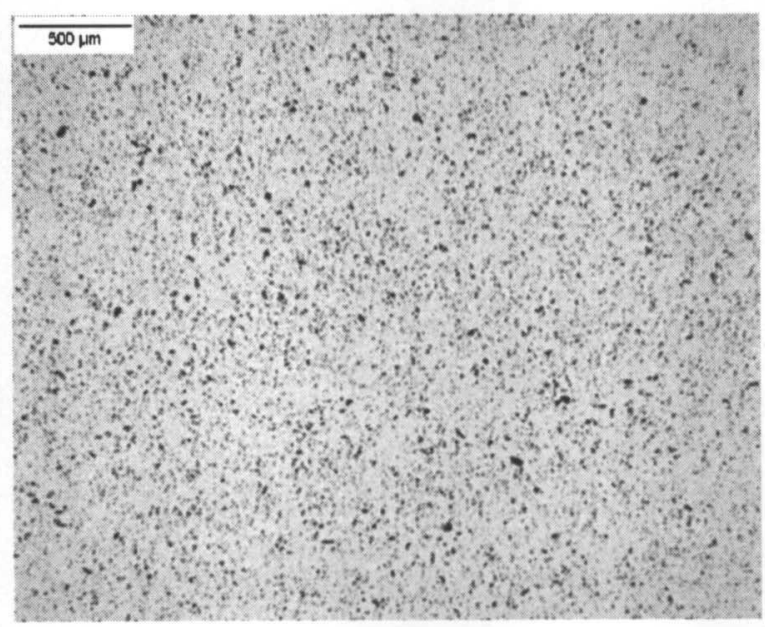

Fig.7-2 Centre of cross section of 316w TS-bar at higher magnification.

measurement of roundness was noted for each of the rings. The closer the value was to 0 , the closer the ring was to perfect circularity. In order to eliminate the effect of the filling direction the green ring were set in random direction before measurements took place. The sintered rings were then measured in this same direction. The results are presented in Table 7 and are an average of 50 rings.

As can be seen, the warm compacted mix achieves a roundness of $12.27 \mu \mathrm{m}$ as compared to $22.48 \mu \mathrm{m}$ for the cold compacted standard mix. This corresponds to a reduction of dimensional scatter to almost half. This tendency can be the same for SUS316L. This shows that the process of warm compaction generates better dimensional stability when using stainless steel powder.

It should be mentioned that the non-complex geometry of the ring resulted in relatively low scattering values. An even density within components ${ }^{5)}$ with the warm
Table 7 Roundness stability of mixes.

\begin{tabular}{|c|c|c|c|}
\hline \multicolumn{2}{|c|}{ Material } & Roundness & St. dev \\
\hline $409 \mathrm{c}$ & $\begin{array}{c}\text { Green State } \\
\text { (microns) }\end{array}$ & 4.78 & 4.07 \\
\cline { 2 - 4 } & $\begin{array}{c}\text { Sintered State } \\
\text { (microns) }\end{array}$ & 22.48 & 14.69 \\
\hline $409 \mathrm{w}$ & $\begin{array}{c}\text { Green State } \\
\text { (microns) }\end{array}$ & 5.78 & 5.03 \\
\cline { 2 - 4 } & $\begin{array}{c}\text { Sintered State } \\
\text { (microns) }\end{array}$ & 12.27 & 9.54 \\
\hline
\end{tabular}

compaction should be better to control the dimensions of complex component too.

\section{Conclusions}

(1) The green density of stainless steel powders is increased with $>0.2 \mathrm{~g} / \mathrm{cm}^{3}$ by the means of warm compaction.

(2) The green strength of stainless steel powders is increased substantially by the means of warm compaction.

(3) Warm compaction of stainless steel powders results in higher sintered density with less dimensional change as compared to cold compaction.

(4) Warm compacted stainless steel powders exhibit a more even porosity distribution, with fewer amounts of large pores.

(5) Warm compaction gives us possibility to produce more accurate components.

(6) Austenitic stainless $316 \mathrm{~L}$ provides less dimensional change than Ferritic stainless 409L.

(7) Phosphorous additions to $316 \mathrm{~L}$ activate sintering and increase mechanical properties but induce higher dimensional change as compared to both cold and warm compaction.

\section{References}

1) A.Bergkvist: "Warm compaction of stainless steel powders", Powder Metallurgy World Congress, Granada, 3(1998)41-446.

2) S.Shah, J.R.Mcmillen, P.K.Samal and E.Klar: "Development of powder metal stainless steel materials for exhaust system applications", 1998 Society of automotive engineers, Inc, 107(1998)171-180.

3) T.Hubbard, K.Couchman and C.Lall: "Performance of Stainless Steel P/M Materials in Elevated Temperature Applications", International Congress \& Exposition, Detroit Michigan, 1997, SAE Technical Paper Series, 970422, 1-11.

4) R.Canto Leyton and O.Andersson: "High density 
sintered stainless steel with close tolerances", World Congress on powder metallurgy \& particulate materials, Orlando, (2002).

5) U.Engström: "High performance PM materials by warm compaction of Densmix powders", Powder Metallurgy World Congress, Vancouver, (1999).
6) "Höganäs Iron and steel powders for sintered components", Höganäs, (2002).

7) A.Molinari, L.Fedrizzi and D.Fax: "How phosphorous affects the mechanical properties and corrosion resistance of P/M stainless steel", International journal of powder metallurgy, 38(2002)41-50. 